University of Michigan Law School University of Michigan Law School Scholarship Repository

1910

\title{
Influence of Social and Economic Ideals on the Law of Malicious Torts
}

W. Gordon Stoner

University of Michigan Law School

Available at: https://repository.law.umich.edu/articles/1097

Follow this and additional works at: https://repository.law.umich.edu/articles

Part of the Common Law Commons, Comparative and Foreign Law Commons, and the Torts Commons

\section{Recommended Citation}

Stoner, W. Gordon. "Influence of Social and Economic Ideals on the Law of Malicious Torts." Mich. L. Rev. 8 (1910): 468-81.

This Article is brought to you for free and open access by the Faculty Scholarship at University of Michigan Law School Scholarship Repository. It has been accepted for inclusion in Articles by an authorized administrator of University of Michigan Law School Scholarship Repository. For more information, please contact mlaw.repository@umich.edu. 


\section{THE INFLUENCE OF SOCIAL AND ECONOMIC IDEALS ON THE LAW OF MALICIOUS TORTS.}

$667 \mathrm{HE}$ existence and the alteration of human institutions," says DICEY, "must in a sense, always and everywhere depend upon the beliefs or feelings, or, in other words, upon the opinion of the society in which such institutions flourish." I Undoubtedly, law, as much as any other human institution, has felt this infuence of public opinion. The political, economical and ethical ideals of a people find expression in their laws. True it is that public opinion is usually, if not always, in the lead, but in a truly happy and contented society the distance is never great. As MaINE says, in progressive societies "it may be laid down that social necessities and social opinions are always more or. less in advance of the law. We may come indefinitely near to the closing of the gap between them but it has a perpetual tendency to reopen. Law is stable; the societies we are speaking of are progressive. The greater or less happiness of a people depends on the degree of promtitude with which the gulf is narrowed."2

According to DiCEY, this is less true of judge-made law than of statutes. Three reasons are assigned for this conclusion, (I) that judicial legislation, more than the enactments of the law-giving body, aims at the maintenance of the logic or symmetry of the law; (2) that it aims at securing the certainty, rather than at amending the deficiencies of the law; and (3) that, because of the age and training of our judges, the ideas of expediency or policy accepted by the courts may differ materially from the ideas "which, at a given time, having acquired predominant influence among the general public," guide the legislative body in making the statutes." Had he been writing with regard to our country instead of England, he might have added as a fourth reason, the peculiar influence which our express constitutional separation of - powers-legislative, judicial and executive-may have upon our judges. It is not strange that under such a constitution judges should give more weight to precedent and consistency in reaching conclusions, even when they feel that such conclusions are not in accord with modern thinking, than they would under a system of government where the division between judicial and legislative powers is not so clearly marked. The

\footnotetext{
1 Dicey, Lectures on the Relation Between Law and Public Opinion in England During the Nipeteenth Century, p. I.

2 Maine, Ancient Iraw, p. 23.

3 Dicey, Idem, pp. 360-376.
} 
natural result of such an expfess division of powers is to make the judiciary slow to render decisions which cause a marked change in the interpretation of laws and so have the practical effect of legislation-it has a tendency to compel care on the part of the judges lest they encroach upon the domain of the legislative body.

Conceding that these reasons are effective and that judge-made law is less likely than statute law to be representative of public ideals and opinion, there is one very pertinent reason why this should be less true here than in England. In four-fifths, or more, of our states the judiciary is chosen periodically by popular election. Even though we may deplore this condition, we must concede that this method of choice affects the judge in like manner as it does the legislator, i.e., it tends to make his decisions coincide with public opinion in his section of the country. The different view-points of the typical English and American judges on this matter is well illustrated by the following quotations. Justice PARK, in his opinion in Mirehouse v. Rennell," said, "Our common law system consists in the applying to new combinations of circumstances those rules of law which we derive from legal principles and judicial precedents; and for the sake of attaining uniformity, consistency and certainty, we must apply those rules, where they are not plainly unreasonable and inconvenient, to all cases which arise; and we are not at liberty to reject them, and to abandon all analogy to them, in those to which they have not yet been judicially applied, because we think that the rules are not as convenient and reasonable as we ourselves could have devised. It appears to me to be of great importance to keep this principle of decision steadily in view, not merely for the determination of the particular case, but for the interests of law as a science." Here the emphasis is laid on uniformity and consistency. Compare with this the following extract from the opinion of Justice ELIIOTT in Tuttle v. Buck," "It must be remembered that the common law is the result of growth and that its development has been determined by the social needs of the community which it governs. It is the resultant of conflicting social forces, and those forces which are for the time dominant leave their impress upon the law. It is of judicial origin, and seeks to establish doctrines and rules for the determination, protection, and enforcement of legal rights. Manifestly it must change as society changes and new rights are recognized. To be an efficient instrument, and not a mere abstraction, it must gradually adapt itself to changed conditions. Necessarily its form

1 Cl. and Fin. 527-546.

107 Minn. 145, 148. - 
and substance have been greatly affected by prevalent economic theories." In this statement it is the adaptability to social needs that is emphasized. We may be, then, not unwarranted in expecting to find the decisions of our courts reflecting with a greater or less degree of faithfulness the economic and social ideals of the public.

Will an examination of the American decisions on some one branch of the law justify this conclusion? Let us seek the answer to this question by a thorough consideration of the law of malicious torts. This particular subject is chosen for the field of our investigation for two reasons, first, because the law respecting it is almost entirely the product of judicial decision, and, second, because within this division of the field of law falls a large proportion of the cases dealing with business competition and the use of the boycott in disputes between labor and capital. These two questions are the subject of present public interest and a prolific source of recent litigation. Consequently the law relating to both of these mattershas been developed largely within the last decade, and promises large. future development, and for this reason, alone, is well suited to our purpose.

Before entering upon the investigation suggested it is necessary to determine what the public economic and social ideals.of our people have been since our national existence began. As is usual with a young and developing country, rich in natural resources and full of opportunities, we were, during the first century of our national existence, an intensely individualistic people. We were strong believers in non-interference on the part of the government with individual freedom of action. As has been suggested ${ }^{B}$ this freedom of action was interpreted as the freedom of action of those in control and unrestrained opportunity to acquire wealth. There was manifested the usual tendency of an individualistic people-a tendency toward absolute rights, both personal and of property. In one respect, at least, we were inconsistent in our belief, for we began early to foster the manufacturing industry by means of a protective tariff.. But as a nation, until recent times, we may be said to have subscribed to the individualistic doctrine of unlimited and unrestrained competition within our own boundaries. Our experience has been the common experience of all peoples which have adhered to this theorywe have fourd that when allowed to go on unrestrained and unlimited competition tends to combination and combination, to monopoly, at which point the benefits of competition are eliminated.

- Andrew Alexander Bruce-Laissez Faire and the Supreme Court of the United States, 20 Green Bag 546, 549 . 
In recent years we have reached a stage in our economic thinking where we do not regard unlimited competition as a necessary, or even desirable condition. It is now quite generally recognized that: limits must be placed on competition if we are to enjoy its beneficial elements. As one writer on economics has expressed it, it is now regarded as one of the functions of government to "raise the ethicar level of competition." $\mathrm{Few}$, if any, rights are now recognized as absolute. In short, we are coming more and more to measure our approval or disapproval of acts by the effect they have upon society as a whole, and public opinion is fast approaching a stage where it will no longer approve an act which though beneficial to the individual is detrimental to society.

The body of the law of malicious torts is not a new development. As far back as the time of Justinian the Roman law provided that one might dig a well on his own land and incur no liability even. though he tapped the vein which fed his neighbor's well and thereby diminished or destroyed his neighbor's water-supply, provided the act were not done for the purely malicious purpose of injuring his. neighbor. ${ }^{8}$ The English courts have not been so ready to consider the motive with which an act is done as of consequence.in affecting the injured party's right of action. Consequently they have held that a landowner has a right to sink wells on his own land and may do. so without incurring liability even though his motive is solely to. diminish, pollute or destroy the water-supply in wells on neighboring property and his act accomplishes that result. ${ }^{9}$ The question of the effect of a malicious motive to render one liable for inducing a breach of contract has caused the English courts no little trouble.10 But the law now seems to be that "a violation of a legal right committed knowingly is a cause of action and ... it is a violation of a legal right to interfere with contractural relations recognized by law if there be no sufficient justification for the interference."11 In one of the cases on this subject, Allen v. Flood, ${ }^{12}$ there is dictum to the effect that an act otherwise legal could not be made unlawful because

\footnotetext{
? Henry Carter Adams-The Relation of the'State to Industrial Action, Publications: of the American Economic Assn., Vol. 1, No. 6, Jan., 1887, pp. 507, 508 .

- Digest-39-3-21; also 39-3-I-22.

- Mayor, etc. of Bradford v. Pickles (1895), 64 I. J. Rep. (Ch.) 759.

${ }^{30}$ Lumley v. Gye (1853), 2 El. \& Bl. 216; Bowen v. Hall (r88r), 6 Q. B. Div. 333; Mogul Steamship Co. v. MacGregor (1889), 23 Q. B. Div, 598; Temperton v. RusselI [1893], I Q. B. 715; Flood v. Jackson [1895], 2 Q. B. 21; Allen v. Flood, [1898] A. C. I; Quinn v. Leathem, [190r] A. C. 495; Read v. Friendly Society, etc., [1902]' 2 K. B. 732; Glamorgan Coal Co. Ltd. et al. v. South Wales Miners' Federation, et al,, [1903] $=$ K. B. 545 .

"2 Quinn v. Leathem, supra.

12 [1898] A. C. I.
} 
it was actuated by malice. According to a later authority ${ }^{13}$ no more was meant by the judges in their opinion in Allen v. Flood than that "san act which does not amount to a legal injury cannot be actionable because it is done with a bad intent." A more recent case ${ }^{\mathbf{1 4}}$ bears out this statement of the law.

In America the cases on no division of the law of malicious torts are altogether harmonious. The majority of cases involving the question of the right of an owner of land to dig a well thereon with the malicious intent of injuring his neighbor's water-supply decide that such conduct constitutes an actionable tort if the plaintiff suffers substantial damage. ${ }^{15}$ In cases where a fence or other obstruction is erected on the property of one person for the sole purpose of injuring and annoying his neighbor the weight of authority is against allowing a recovery by the person whose light, air or view is thereby cut off.18 The legislatures of some states have passed statutes making the erection of structures, useless to the owner of the property and for such a purpose, actionable. ${ }^{17}$

- It seems to be the law of the American cases that one may not induce others not to trade with a third person when the sole purpose of such act is to injure the third person and that one who does such an act is liable to the person injured for the damage which

\footnotetext{
2 Iord Macnaughten in Quinn v. Leathem, supra.

14 Brown v. Magistrates, etc. of Edinburgh et al. (1906), Session Cases (1907) 256.

15 Stillwater Water Co. v. Farmer (1903), 89 Minn. 58, 93 N. W. 907; same case (1904), 92 Minn. 230, 99 N. W. 882; Williams v. Ladew (1894), 161 Pa. St. 283; Barclay 7. Abraham (1903), 121 Iowa 619, $96 \mathrm{~N}$. W. ro80; Chesley v. King (1882), 74 Me. 164; Gagnon v. French Lick Springs Hotel Co. (1904), 163 Ind. 687, 72 N. E. 849; Wyandot CIrb Co. v. Sells (I895), 3 Ohio N. P. 210 ; still other. cases are to the effect that the use of underground, surface and percolating waters must be reasonable and these jurisdictions certainly would not hold that one can diminish or destroy his neighbor's water. supply without rendering himself liable for the damage so caused, where the sole purpose of the inflictor is to injure his neighbor; see Swett v. Cutts (1870), 50 N. H. 439; Bassett v. Salisbury Mfg. Co. (1862), 43 N. H. 569; Franklin v. Durgee (1901), 71 N. H. I86; Forbell v. City of New York (1900), I64 N. Y. 522; Katz v. Walkinshaw (1903), I4I Cal. I16; Cohen v. I,a Canada Land \& Water Co. (1904), I42 Cal. 437; opposed to this view are the following cases Chatfield v. Wilson (1856), 28 Vt. 49; Huber $\nabla$. Merkel (1903), 117 Wis, 355, 94 N. W. 354 .

is Holding that it is an actionable wrong: Flaherty $\nabla$. Moran (1890), 8r Mich. 52; Kirkwood v. Finegan (1893), 95 Mich. 543; Smith v. Speed (I901), II Okla. 95, (not in the higher court on this question). Contra: Metzger v. Hochrern (1900), ro7 Wis. 267; 83 N. W. 308, 50 I. R. A. 305; Bordeau v. Greene (1899), 22 Mont. 254; Letts v. Kessler (1896), 54 Ohio St. 73 ; Guest v. Reynolds ( 1873 ), 68 Ill. 478 ; Adler v. Parr (1901), 34 N. Y. Misc. 482 (by inference though not necessary to decision); Pickard 7. Collins (1856), 23 Barb. 444; Ransom v. McCallister (1887), 9 Ky. L. R. 495 ; Saddler v. Alexander (I900), $2 I$ Ky. I. R. 1835; the Kansas cases lead one to believe that the Kansas courts would also take this view of the question, Falloon $\mathrm{v}$. Sahilling (1883), $29 \mathrm{Kan} .292$; Triplett v. Jackson (1897), 5 Kan. App. 777, 48 Pac. 931.

17 Connecticut, Maine, Washington, Vermont, Massachusetts, and New Hampshire.
} 
he may suffer therefrom. ${ }^{18}$ The same rule applies in cases where the defendant induces the discharge of an employee ${ }^{19}$ or induces workmen to leave their employment. ${ }^{20}$ In a recent case it has been decided that one who established a barber shop, employed a barber to carry on the business, and used his personal influence to attract customers from a neighboring shop, for the sole purpose of injuring his neighbor by ruining his business, and succeeded in doing so, is liable to the neighboring barber for the injury so resulting. ${ }^{21}$

There are many other American cases on the subject of malicious torts and not within the classes mentioned. It would be a repetition of work done, however, to attempt an exhaustive collection of them. Many collections of cases and articles on this subject have appeared during recent years and are of inestimable value to a student of the subject..22 The general conclusion of all the recent writers on this subject seems to be that, if it has not always been so, the law now, at least, is that one who with the sole intent of injuring another and

${ }^{28}$ Ertz v. Produce Exchange (1900), 79 Minn. 140, 81 N. W. 737, 48 L. R. A. 90; Iohse Patent Door Co. v. Fuelle et al. (1908), 215 MO. 421, 114 S. W. 997 ; Klingel's. Pharmacy v. Sharpe \& Dohme et al. (Ig06), I04 Md. 218, 64 Atl. 1029, 7 I. R. A. (N. S.) 976; Graham v. St. Charles St. R. R. Co. (1895), 47 I.a. Ann. 214 and 1656; Crump v. Commonwealth ( 1888 ), 84 Va. 927; Delz v. Winfree, Normari \& Pearson et al. (189r), 8o Tex. 400; Olive Sternenberg v. Van Patten et al. (1894), 7 Tex. Civ. App. 630; Moores \& Co. v. Bricklayers' Union et al. (1899), 23 Ohio Wk. Bul. 48, 1o Ohio Dec. (Reprint) 665. Contra: J. F. Parkinson Co. v. Building Trades Council (1908), - Cal. -, 98 Pac. 1027; Guethler v. Altman (Ig0r), 26 Ind. App. 588, 60 N, E. 355 ; Heywood v. Tillson ( 5883 ), 75 Me. 225.

10 Chipley v. Atkinson (1887), 23 Fla. 206; Huskie v. Grifin (1909), - N. H. -, 74 Atl. 595; Erdman v. Mfitchell (1903), $207 \mathrm{~Pa}$. St. 79, here the immediate purpose of the persuasion or coercion was to secure the discharge of non-union men in order to result remotely in strengthening the union; see also Plant v. Woods (r900), 176 Mass. 492. Contra: National Protective Assn. of Steam Fitters \& Helpers v. Cumming. et al. (1902), 17o N. Y. $3 \times 5$.

20 Walker v. Cronin (1871), 107 Mass. 555.

21 Tuttle v. Buck (1909), 107 Minn. 145; but see, Passaic Print Works v. Ely \& Walker Dry Goods Co. et al. (1900), ro5 Fed. Rep. I63.

$=2$ William L. Hodge-Wrongful Interference by Third Parties with the Rights of Employers and Employed-28 Am. L. Rev. 47.

F. P. Walton-Motive as an Element in Torts in the Common and in the Civil: Law-22 Harv. I. Rev. 50I.

J. B. James-How Far an Act May Be a Tort Because of the Wrongful Motive of the Actor-I8 Harv. L. Rev. $4 \mathrm{II}$.

Henry T. Terry-Malicious Torts-20 Law Quart. Rev. 10.

William Draper Lewis-Should the Motive of the Defendant Affect the Question of his Liability?-The Answer of one Class of Trade and Labor Cases-5 Col. I. Rev. 107.

Jeremiah Smith-Crucial Issues in Labor Litigation-20 Harv. I. Rev. 253-279, 345-362 and 429-453. The effect of bad motive is taken up at page $45 \mathrm{I}$, et seq. Maliciously Inducing a Breach of Contract-2 Mich. L. Rev. 305.

Effect of Bad Motive to Make Actionable What Would Otherwise not Be--Note,

62 L. R. A. 673 .

Interference with Contractual Relations-Note, 8 Col. L. Rev. 496.

Motive Affecting Iegality of Competition-Note, 9 Col. L. Rev. 455. 
without any benefit to himself does an act which results in injury to such other person is liable to the person so injured. In many cases the judges in their opinions have enunciated the principle that "the commission of a lawful act is not actionable though it proceeded from a malicious motive," or sometimes stated "an act which is lawful in itself cannot be made actionable because of the motive which induced it," or "where one exercises a legal right only, the motive which actuates him is immaterial."23 With the actual results in many, if not all, of these cases one has no quarrel, but such a statement of the general principle is misleading and, for that reason, dangerous. If by these statements is meant, simply, that an act, which one may do at any time, under any circumstances and with any motive, may be done without incurring liability where the intent of the inflictor is solely to injure another, no one will disagree, for the premises assume that the right exercised is absolute and the statement becomes a.mere truism. But if the interpretation of such statements is that any right which one may exercise where his object is to benefit himself materially even though in its exercise he injure his neighibor, may be exercised to the injury of another where the sole purpose of the person so exercising it is to injure the other, then it is manifestly incorrect. If the right is absolute, this latter statement is, of course, true, as by definition an absolute right is one which may be exercised under any condition. We recognize, however, very few, if any, rights as being absolute, and the principle as stated above is likely to be incorrectly applied to rights that are not absolute with disastrous effects as regards the justice of the law.

How do these various lines of cases reflect public opinion? As suggested, one of the characteristics of individualistic thinking is a tendency to regard rights as absolute. The influence of this tendency is clearly traceable in the decisions involving the law of mali.cious torts. By far the majority of the cases before $1890,{ }^{24}$ and a number of the later ones ${ }^{25}$ were decided on the basis that the rights in question were absolute, or if not absolute, that the limitations on them should not be extended as logic required. A good illustration

23 Raycroft 7. Tayntor (1896), 68 Vt. 229, 54 Am. St. Rep. 882, 33 I. R. A. 225 ; Jenkins v. Fowler (1855), 24 Pa. St. 308; Fowler v. Jenkins (1857), $28 \mathrm{~Pa}$. St. 176; Glendon Iron Co. v. Uhler (1874), $75 \mathrm{~Pa}$. St. 467; Thornton v. Thornton (1869), 63 N. Car. 211 ; Auburn \& Cato. Plank Road Co. v. Douglass (1854), 9 N. Y. 444; Phelps v. Nowlen (1878), 72 N. Y. 39; Chatfield v. Wilson (1856), 28 Vt. 49 ; Metzger v. Hochrein (1900), 107 Wis. 267; Huber $\nabla$. Merkel (1903), 117 Wis. 355 .

is Phelps v. Nowlen, supra; Mahan v. Brown (1835), I3 Wend. 26I; Payne v. Western \& Atlantic R. R. Co. (1884), I3 Lea (Tenn.) 507.

25 Metzger v. Hochrein, supra; Guethler v. Altman (I901), 26 Ind. App. 587, 60 IN. E. 355; Boyson v. Thorn (I893), 98 Cal. 578; Loehr v. Dickson (1910), - Wis. -, 124 N. W. 293 . 
of this is furnished by the case of Phelps v. Nowlen; ; $^{26}$ the defendant in this case had on his land a mineral spring about which there was an embankment formed by the action of the water and by artificial means. The plaintiff dug a well on his land and struck a vein of mineral water; he then laid a pipe and conducted the water to a bath-house and fountain. The defendant supposing that there was some connection between his spring and the well of the plaintiff with the sole intent of injuring plaintiff by diminishing his watersupply dug a ditch through the embankment about his spring. This resulted in lowering materially the water-supply in plaintiff's well, thereby cutting off the supply of water to the plaintiff's bath-house and fountain. The lower court found, "that the defendant had an absolute right to dig the ditch and lower the spring on his own land $\ldots$ and that with whatever motive he acted, he invaded no legal right of the plaintiff in so doing." The higher court sustained the decision of the trial court. Judge MIILER in his opinion said, "While the law does not allow an owner to erect on his own land, near the house of another, structures for carrying on an unwholesome and obnoxious trade, which may poison the air and constitute a nuisance that interferes with a proper enjoyment of the property of an adjoining owner, and does not permit a person, in any form, to disturb a legitimate use of another's property, it also does not interpose its shield for the protection of such owner in what does not actually belong to him." Here it is evident that the judge while recognizing that the right of the owner of property to use it as he sees fit is not absolute, but is limited in that he may not use it to carry on an "unwholesome or obnoxious trade" that may interfere with a proper enjoyment of the property of an adjoining neighbor, refuses to extend the limitation of the right of property so as to deny the owner thereof the right to dig a ditch thereon, which does himself no good and injures his neighbor quite as seriously as would be the case were he to engage on his land in an obnoxious trade. It is as logical, certainly, to extend the limitation to refusal to allow the destruction of a water-supply as to the pollution of the air. But Justice MILLER's decision is quite in accord with the tendency, until recently evidenced by public opinion, to regard one's right to property as absolute-to consider that the owner should be allowed to use it as he desired even though he derived, or intended to derive, no benefit or pleasure from such use and did cause inconvenience and damage to his neighbor.

In another case, Payne v. Western \& Atlantic Railroad Company, ${ }^{28}$

${ }^{28} 72$ N. Y. 39.

$z_{13}$ Lea (Tenn.) 507. 
the defendant published a notice to employees threatening to discharge any of them who should trade with the plaintiff. The order was made for the sole purpose of injuring the plaintiff. This resulted in a severe loss of trade to the plaintiff and he sued the defendant to recover the damages suffered. In this opinion Justice INGERSOLI, said, "The only act complained of is the notice to hands that they will be discharged if they trade with the plaintiff. This. being merely the exercise of an undoubted right by defendant, cannot give plaintiff a right of action, even though the act was malicioisly done, and the plaintiff suffered injury therefrom." It is evident here that the judge regarded the right to induce workmen, by means of threats or persuasion, to cease trading with the plaintiff as an absolute right to be exercised at any time, under any circumstances and with any motive without incurring any liability. This same general tendency to regard rights as absolute is evidenced by a great number of cases. ${ }^{28}$ It is one of the expressions of the individualistic system of thinking.

Another characteristic of this system of thought is reverence for any act which bears the form of business competition. This is true whether the act or acts in question constitute what economists designate as competition or whether they are simply malicious interference with the business of another masquerading as competition. One of the best examples of this view is furnished by the case of Passaic Print Works v. Ely \& Walker Dry Goods Company. ${ }^{28}$ The plaintiff in this case was a corporation engaged in manufacturing prints or calicoes. The defendant was a wholesale dry-goods corporation and for the sole and malicious purpose of injuring plaintiff's business issued a circular to plaintiff's customers advertising to sell prints manufactured by the plaintiff at a price very much below that at which the plaintiff sold them. The result was to greatly injure plaintiff's business by destroying its trade, and for the damage suffered plaintiff sued the defendant.. The court, Judge SANBORN dissenting, held that the plaintiff could not recover. In his opinion Judge THAYER said, "No one can dispute the right of the defendant company to offer for sale goods that it owned and were in its possession, whether- the quantity was great or small, for such price as it deemed proper. This was the outward visible act of which complaint is made, and, being lawful, the law will not hold it to be otherwise because of a secret purpose entertained by the defendant company to

23 See cases cited under note No. 23; also Heywood v. Tillson (1883), 75 Me. 225;

Guethler v. Altman, supra; Loehr v. Dickson, supra.

20 (1900) x05 Fed. I63.

Page. 167. 
inflict loss on the plaintiff by compelling it to reduce the cost of a certain kind of its prints or calicoes." The court's position here clearly is that the defendant having the right to sell goods, which it owns, at any price it chooses where its purpose is simply to attract customers to itself, or to turn the goods into money, or some other such legitimate purpose where the immediate motive is to materially benefit itself, has the same right to sell where its motive is solely to injure and damage the defendant. This is, in substance, saying that in business whenever acts take the form of competition they are not to be interfered with even though they injure another and render no immediate benefit to the inflictor. Again this is but another manifestation of the doctrine of absolute rights-one has a right to sell goods which he owns where his motive is to benefit himself, so he has the right to do so no matter what his motive. It is a contradiction to denominate such acts competition. One of the necessary elements of business competition is an intent on the part of the one doing the act or acts to advance or benefit his business.

In a great many of the more recent cases the courts have recognized that few, if any, rights are absolute and that many rights which have in the past been regarded as absolute must be limited for so-

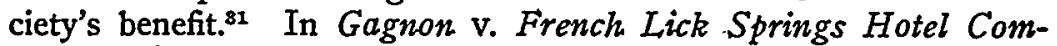
pany, ${ }^{32}$ which was an action by the complainant for an injunction against the defendant to restrain defendant from pumping large quantities of water from a well on his own land for the sole purpose of injuring the plaintiff, Judge DowLING in his opinion said, "The strong trend of the later decisions is toward a qualification of the earlier doctrine that the landowner could exercise unlimited and irresponsible control over subterranean waters on his own land, without regard to the injuries which might thereby result to the-land of other proprietors in the neighborhood. Local conditions, the purpose for which the landowner excavates or drills wells on his land, the use or non-use intended to be made of the water, and other like circumstances have come to be regarded as more or less influential in this class of cases, and have justly led to an extension of the maxim, 'Sic utere tuo ut alienum non laedas,' to the rights of landowners over subterranean waters, and to some abridgment of their supposed power to injure their neighbors without benefiting themselves." Judge ELLIOTT applies this same view of the necessity of limiting

2 Delz v. Winfree, Norman \& Pearson et al. (189r), 80 Tex. 400; Klingel's Pharmacy v. Sharp \& Dohme (1906), I04 Md. 218; Gagnon v. French Lick Springs Hotel Co. (1904), I63 Ind. 687, 72 N. E. 849 ; Huskie v. Griffin (I909), - N. H. 74 Atl. 595; Thacker Coal \& Coke Company v. Burke et al. (1906), 59 W. Va. 253. 53 S. E. I6I; Willner v. Silverman et al. (1909), rog Md. 34I, 7I Atl. 962.

563 Ind. 687 . 
absolute rights to a different situation. In his opinion in Tuttle v. $B u c k,{ }^{33}$ he says, "The principle that a man may use his own property according to his own needs and desires, while true in the abstract, is subject to many limitations in the concrete. Men cannot always, in civilized society, be allowed to use their own property as their interests and desires may dictate without reference to the fact that they have neighbors whose rights are as sacred as their own. The existence and well-being of society require that each and every person shall conduct himself consistently with the fact that he is a social and reasonable person. The purpose for which a man is using his property may thus sometimes determine his rights." Both of these quotations evince a tendency on the part of the judges to look primarily to the welfare of society rather than to the advancement of individual interests at the expense of society. Other cases indicate that the courts are gradually coming to take this view, $i . e_{\text {., that }}$ the rights of the individual are not to be regarded as absolute but are rather to be limited where the limitation results in a benefit to so- . ciety as a whole. ${ }^{34}$

In other words, the courts of this country are coming to adopt the view that the answer to the question, may one, without incurring liability, exercise what has hitherto been regarded as a right in such a manner as to cause loss or damage to another depends largely on the reasonableness of the purpose for which he exercises it. The most certain way of avoiding difficulty and conflict in cases of this sort is the adoption of the rule that where one is injured or damaged by the act of another, he is entitled to be recompensed therefor, unless the said damage is caused by the exercise of an absolute right of the inflictor or unless the purpose sought to be accomplished by such act justifies it, i.e., is reasonable. This rule or an approach to it has been adopted in some of the recent cases. Judge SANBoRN in his dissenting opinion in Passaic Print Works v. Walker Dry Goods Company," says, "The general rule is that, whenever one injures a man's business, profession, or occupation he is liable for the damages he inflicts. The exception is that, where the injury is caused by competition in trade, or the lawful exercise of a right which the inflictor has, then the injury is justifiable, and no damages can be recovered. But where such an injury is inflicted, the presumption always is that the rule, and not the exception, applies, and, if the inflictor would justify, he must show that he falls within the

\footnotetext{
so 107 Minn. 145.

4 Tuttle v. Buck, supra; Gagnon v. French Lick Springs Hotel Co., 163 Ind. 687; Stillwater Water Co. v. Farmer, 89 Minn. 58; Erdman v. Mitchell (1903), 207 Pa. St. 79.

${ }_{35}$ Ios Fed. 163 , at page 167 .
} 
exception." In this statement Judge SANBORN approaches a statement of the rule suggested as a way out of the difficulty. It should not be confined to injuries to one's "business, profession, or occupation," but extended so as to embrace injuries to any right, including what Mr. Terry ${ }^{36}$ denominates "the right of pecuniary condition." An adoption of this rule, with the courts determining the reasonableness of the act causing the injury by comparing its effect on society with the effect of the injury thereby caused, would remove many of the difficulties in the law of malicious torts and would undoubtedly secure more just results in cases involving this law. The adoption of this rule would mean the recognition of fewer absolute rights, and these would be those, the recognition of which according to our present economical and social ideals seem beneficial to society, as for instance the right to use the courts to enforce a just claim even though in special instances they may be made use of to annoy rather than for the purpose of collecting the claim.

The conclusion, then, which one may justly draw from an examination of the cases along this branch of the law, is that the courts are generally following public opinion in this regard. To be sure, there are recent instances, and perhaps too many of them, where the courts apparently still cling to the old individualistic way of thinking. ${ }^{37}$ These instances seem to be becoming fewer each year, however, and we may expect to see our decisions in the immediate future approaching more nearly the public ideals.

It is interesting to consider what the result would be if the rule suggested were followed out logically in cases where trusts, large corporations or combinations of corporations, attempting to gain control and secure a monopoly of the business in some one line, seek to destroy independent corporations engaged in the same line of business. In the labor cases involving motive, the courts have drawn a distinction between what they term the "immediate" and the "ultimate" motives of the inflictor of the injury. By "immediate" motive is meant the immediate result which is desired to be accomplished by the act. The "ultimate" motive is the result which the inflictor wishes to accomplish not by the act itself but by that act as one of a series of acts. To illustrate, suppose a labor union, some of whose members are employed by a manufacturer, who also employs nonunion men, orders him to discharge the non-union men and threatens to compel its men to quit work if he does not comply with the order. To avoid a strike he discharges the non-union men. Here the imme-

st 20 Law Quart. Rev. I4.

st Loehr v. Dickson, Huber v. Merkel, and Metzger v. Hochrein, all supra. 
diate result desired is the injury-the discharge-of the non-union men. It may very well be that the ultimate motive is to force all laborers to join the union and thus to increase its power and usefulness. It may be stated as a general rule that in labor cases the courts have not regarded the ultimate motive of the defendants in determining their liability. ${ }^{38}$ Suppose this principle were to be applied in the same way in suits brought by an independent company against a trust where the trust has cut prices so as to lose money in the district where it competes with the independent company, in order to drive the independent concern out of business and so to destroy it or force it to enter the combination to preserve itself. Here the immediate motive is the injury or destruction of the plaintiff company, the ultimate motive, the benefit to be derived by the trust through forcing the independent concern-to unite with it or go out of business. For a time while the rival concerns are cutting prices and selling below the manufacturing cost, the trust; as well as the independent company, is losing money, and so the immediate result to the trust is an injury. Apply the principles suggested as they are applied in labor cases and the result will be as follows: the inde- pendent concern is injured by the acts of the trust, therefore it has an action unless the acts are justified; the right to sell goods is not absolute but depends upon the motive of the owner, i.e., if the owner sells the goods for the sole purpose of injuring his neighbor, he is not excused from liability; in considering the motive, the immediate motive alone will be regarded; but in this case the immediate motive of the trust is the injury of the plaintiff company and the immediate result, even to the defendant, is a loss; therefore the defendant, the trust, is liable in damages to the plaintiff, the independent concern, for the injury caused. There was a time when the public reverence for competition would have insured a different result. Had the question of the justification of the act been raised, it would have been answered by the statement that the acts were done under competition and so were justified, it being considered dangerous to the public welfare to restrict competition. As has been suggested earlier in this article, as a nation our views on the sacredness of competition have changed. The public in general is fast coming to see, if it does not already recognize, that though it is benefited for a time when price cutting is going on between the two concerns, the final result is detrimental to it, as the usual result, when the independent company is destroyed or driven to join the

23 Plant 8 . Woods (1900), 176 Mass. 482-though the dissenting opinion of Justice Holmes seems to be to the contrary; Fidman v. Mitchell (1903), $207 \mathrm{~Pa}$. St. 79. 
combination, is an increase and maintenance of prices above the level which they occupied when the price cutting began. If public opinion reaches the stage where it recognizes that competition ought to be so limited as to prohibit such acts, what will the result be? As explained, the way is open. If our judges regard public opinion, revolutionary as it may seem, will they not reach the result suggested above?

UNIVERSITY OF MICHIGAN.

GORDON STONER. 